Ol'ga Dedkova*, Irina Polyakova*

\title{
Development of Mass Valuation in Republic of Belarus
}

Abstract: This article covers the current and prospective situation in the mass valuation system in the Republic of Belarus, focusing on the use of different types of information in the valuation process. The paper deals with the mass valuation of such types of land as urban and rural areas, territories outside the settlements, land for collective gardening, and placement of summer houses. The mass valuation system of land for agricultural purposes is not related in the article.

Keywords: mass valuation, market information, the pilot project, National Cadastral Agency, estimation procedures

* National Cadastral Agency, Minsk, Belarus 


\section{General Description of Mass Valuation System in Republic of Belarus}

In spite of the restriction for transactions with land plots on the open market, the objects of mass valuation is a land plot and a value zone. According to hands-on experience, land mass valuation is provided by allocating a share of a land plot from the value of a real estate unit or by using market information on the results of the public auctions of land plots.

The main legislative act that provides regulation of the mass valuation system is the land code that describes the cadastral valuation of a land and land plots as a mass valuation process on the effective date as well as for purposes that are specified in Belarusian law [1]. In other words, it is a systematic appraisal of groups of land and land plots using market information (which includes market transactions, offers for rent and sell, and public auctions), data about the characteristics of real estate objects, standardized procedures, and statistical testing. In the case of the sufficiency of market information, the calculated cadastral value is in the neighborhood of market value.

Other legislative acts within the sphere of mass valuation are as follows:

- The decree of the President of the Republic of Belarus of October 13, 2006, № 615 in the Republic of Belarus "on appraisal activities in the Republic of Belarus" (with amendments);

- The instruction on the procedure of the mass valuation of land and land plots for urban and rural areas as well as land for collective gardening associations and country cooperatives. It was claimed by the decision of the State Committee on Property of the Republic of Belarus of June 29, 2015, № 27;

- State standards of the Republic of Belarus on appraisal activity;

- Technical Codes of common appraisal practice.

The value is estimated for five types of functional use: land for placement of multi-dwelling houses, single-family houses (including collective gardening associations and country cooperatives), commercial property, industrial property, and recreational facilities. The cadastral value is calculated in two currencies: Belarusian rubles and US dollars.

\section{Past and Present of Mass Valuation System in Republic of Belarus}

The history of the mass valuation system in the Republic of Belarus started in 1998, when the basic principles of the mass valuation process and methodology were developed. Simultaneously, the key points of a taxation system were formed, because it is connected to the mass valuation system. 
From its inception, the mass valuation system in the Republic of Belarus has undergone changes. In 2010, the mass valuation system assumed an ever-greater importance because the cadastral value became the tax base for land payments. This fact explains the substantial role of the mass valuation system for the entire country: fair cadastral value ensures the main rights of the taxpayers and provides fair and accurate payments. The mass valuation standards became centralized in 2015 (one executer, one customer, one budget, one functional use per year of assessment, one methodology for the whole territory of the country).

Key aspects of the centralized mass valuation system are as follows [2]:

- The State Committee on Property of the Republic of Belarus initiates appraisal procedures, chooses an executer, pays expenses for the assessment, and approves the schedule of mass valuation work (Tab. 1) [3].

Table 1. Schedule of mass valuation works

\begin{tabular}{||l|c|c||}
\hline \multicolumn{1}{|c|}{ Functional use } & Period of work execution & Effective date \\
\hline \hline Multi-dwelling houses & january 2015 - June 2016 & July 1, 2015 \\
\hline $\begin{array}{l}\text { Single-family houses, recreational facil- } \\
\text { ities, collective gardening, and placing } \\
\text { summer houses }\end{array}$ & january 2016 - June 2017 & July 1, 2016 \\
\hline Commercial property & january 2017 - June 2018 & July 1, 2017 \\
\hline Industrial property & january 2018 - November 2018 & July 1, 2018 \\
\hline Multi-dwelling houses & december 2018 - June 2020 & July 1, 2019 \\
\hline $\begin{array}{l}\text { Single-family houses, recreational facil- } \\
\text { ities, collective gardening associations, } \\
\text { and placing summer houses }\end{array}$ & january 2020 - June 2021 & July 1, 2020 \\
\hline Commercial property & january 2021 - June 2022 & July 1, 2021 \\
\hline Industrial property & january 2022 - June 2023 & July 1, 2022 \\
\hline
\end{tabular}

Source: www.nca.by

- Only state-owned companies (the government's share in the statutory fund shall be more than 50\%) can be the executor of a mass appraisal. For the current valuation cycle, the National Cadastral Agency was chosen as the executor of mass appraisal. Besides this, the National Cadastral Agency involves other territorial government-owned companies in Valuation Process 7 that are responsible for the cadastre ${ }^{1}$, formation, and registration of real property, single-property appraisal. They are charged with duties at different steps of the valuation process such as data collection, model testing, etc.

1 The cadaster in the Republic of Belarus has two dimensions, in contrast to the three-dimensional (3D) cadastres that appear more extensively since the workshop held in Delft in 2001 [4]. 
- The effective date is July 1 of the year of assessment.

- The source of financing mass valuation activities is the Republican budget.

- The periodicity of the mass valuation for one functional use is at least one time every four years.

The centralized character of the mass valuation system has significant advantages [5]:

- There is no violation of revaluation frequency. Previously, the periodicity of revaluation was established for at least one time every five years, and the local government was the customer. However, financial and other problems faced by local governments had an influence on the placement of mass valuation orders. As a result, mass valuation could take place once every ten years in some territories. Outdated processes that formulate the cadastral value for the current date didn't allow for reasonable decisions about the land and didn't set fair payments.

- The new system provides for the use of uniform appraisal approaches for the entire country and allows for comparable valuation results. In the period of the decentralized system, local authorities selected executers of mass valuation that charged a lower price for their work. As everyone knows, lower prices do not mean higher quality. Consequently, mass appraisal executors carried out assessments using different approaches; in some cases, this led to different values for different territories that should have been comparable.

The basic principle of mass valuation in the Republic of Belarus is an emphasis on market information and using statistical models and market simulation for describing market value to territories with poor market data, which is also a problem in other Central-Eastern European countries [6].

Mass valuation makes it possible to explore the real estate market for the entire country, and it reveals useful trends and indexes. This is why the results of this real estate market research are quite popular among all participants of the business society (single-property appraisers, bank workers, local authorities, owners of real estate, estate agents, developers, inspection officials, etc.). In addition to appraisal reports, the National Cadastral Agency released the results of the research to the public as a product called "Analysis of the real estate market: Minsk, regions" and another called "A short analysis of the real estate market for a certain city." These products are available on the website of the company $[7,8]$.

\section{Steps of Mass Valuation Process}

Data collection and market analysis are the most important steps of the valuation process and take about $70 \%$ of the work time. 
The estimation procedure of mass valuation includes the following steps [9]:

1. Contracting a treaty on mass valuation. In 2015, the State Committee on Property of the Republic of Belarus signed a contract with the National Cadastral Agency to determinate the cadastral value of the land and land plots for each functional use on the whole territory of the country.

2. Data collection and analysis. The list of the data used for cadastral valuation is as follows:

- Data from the unified state register of real estate, rights to it, and transactions with it (the state register of real estate).

- Data from the state register of the prices of the land and land plots of the state land cadastre of the Republic of Belarus (the state real estate price register).

- Data from the unified state register of the administrative-territorial and territorial units (the register of the ATU and TU).

- Information from the address register of the Republic of Belarus.

- Information from local executive and administrative bodies (the executive committees).

- Information from local maintenance services.

- Information from the territorial organizations on state registration and land cadastre.

- Information about offers and rent prices.

- Cartographic information from the digital map data bank owned by the National Cadastral Agency.

- Websites: egr.gov.by, belstat.gov.by, nbrb.by, google.com, yandex.ru, etc.

3. Definition of prerequisites and restrictions. On this stage, the prerequisites and restrictions affecting the cadastral value of land plots are formulated by appraisers depending on the terms of the contract, initial information about real estate objects, data from the real estate market, economic situation, chosen methods of valuation, and other factors.

4. Market analysis. During the analysis of the real estate market, their indicators are considered (prices of purchases and sale transactions, offer prices, rental rates), their dynamics are studied, and the parameters of a norm property are determined for each territory. Further, the territories with similar economic, social, legal, administrative, and physical characteristics are determined and divided into groups.

5. Selection of appraisal approaches and techniques. Depending on the initial information, market approaches (cost, income, comparative approach) or the market simulation method may be applied.

6. Zoning. Land zoning is based on market real estate valuation aspects, availabilities of utilities, and valuation criteria for certain type of the real estate property and administrative divisions. Zoning is carried out on a cartographic basis using geographical information systems. The borders of the land zones can be district and settlement boundaries, parcel lines, streets, roads, rivers, railway roads, and others [10] (Fig. 1). 
Each functional use has individual zoning and numbers. The name of a valuation zone is created from three blocks: the last two digits of the assessment year, a unique territory (settlement) number, and an ordinal number of the territory (for example, $15+17030+001=1517030001$ ). The technology of land zoning is improving year by year, and the number of valuation zones is optimized for a certain functional use. Statistics on the quantity of valuation zones for urban territories (201 cities) is presented in Figure 2 [4, 10]. Land zoning for industrial purposes is under development, so the final number of valuation zones for this land use can be updated later.

7. Calculation of cadastral values for land and land plots. The calculation is made separately for cities, rural areas, and territories outside the settlements according to the chosen assessment model.

8. Model testing, quality control, proof of values. The market value of real estate units is tested by local appraisers, local authorities receive preliminary results, and valuation models are then approved by the State Property Committee.

9. Developing appraisal reports and other documents. This year, the National Cadastral Agency sent out 141 reports to each local authority.

10. Approving valuation results. Local authorities approve the results and send paper confirmation.

11. Publishing the valuation results to the state land value register and providing valuation results to the public. Updated current cadastral values are always available at vl.nca.by. Each person who is interested in a cadastral value of land or a land plot can get this information without cost with help from an opened internet resource (vl.nca.by) or by calling a paid helpline. If necessary, an official document can be provided. For the period of January 1 through December 18,2017 , the number of requests to vl.nca.by was estimated to be 380,815 . This is $28 \%$ more than during the same period one year earlier. These figures show an increasing interest in the Internet resource, especially after modernization.

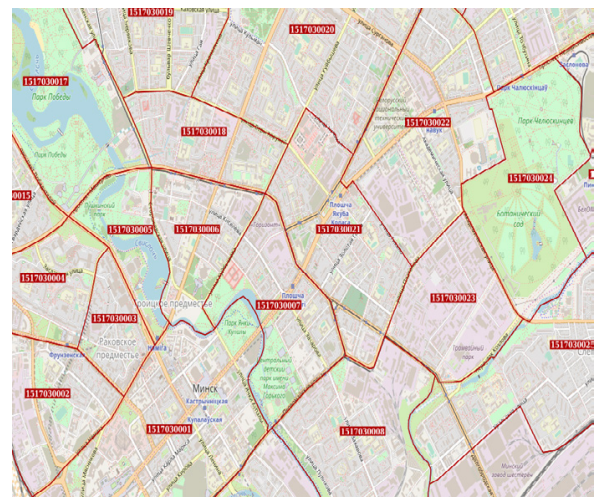

Fig. 1. Land zoning

Source: www.vl.nca.by 


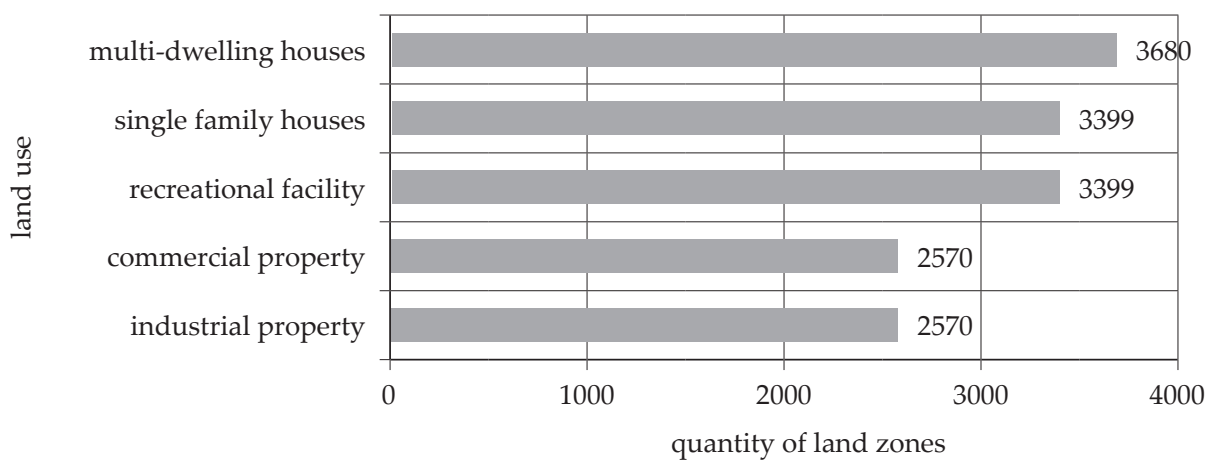

Fig. 2. Statistics on quantity of valuation zones for urban territories (cities) depending on land use

Source: vl.nca.by and work materials of National Cadastral Agency

After approving and publishing the valuation results to the state land value register, they can be used for a diverse range of purposes: rental payment, land tax, price for a land plot in the case of a purchase or public sale to a private property, in the case of eminent domain, and other purposes.

Because of the scale of the mass appraisal, about 35 specialists work on the process: a manager, mass and single-property real estate appraisers, GIS-specialists, business and systems analysts, programmers, lawyers, marketing specialists, and public relations specialists. The synchronous operation of the task allows us to get valuation results in due time and with high-quality results.

\section{Prospect for the Development of the Mass Valuation System}

The next step in developing the mass valuation system might be the mass valuation of real estate objects. The main reason is to place all owners and taxpayers under equal conditions. Nowadays in the Republic of Belarus, an owner pays two types of taxes: a land tax and a real estate tax. The land tax became clear after the implementation of the centralized system and using the same rules to determinate the cadastral land value for the whole country. It is a little more complicated with the real estate tax.

The basis for real estate taxation is the book value for companies or assessed (normative) value for individuals. If such a value doesn't exist yet - then it is according to a basic estimated value of one square meter of a typical building. This way gives a wide range for the basis of a real estate tax [11].

In order to optimize the approaches to real estate taxation, the Belarusian government instructed the State Committee on Property, Ministry of Finance, and 
Ministry of Economy to implement a pilot project on the mass formation and cadastral valuation of real estate in trial areas.

The Kobrin district and the Soviet district of Minsk were chosen as "ground" for the pilot project. They were significantly different from each other, including on the real estate types and the level of prices for each type. Thus, the Kobrin district is the standard on the characteristics of real estate among other regions of the republic. There are all types of real estate objects in the Soviet district of Minsk as well as the largest number. This gave an objective picture for making a balanced management decision, including the determination of tax rates.

The pilot project was carried out from January 2015 through June 2016.

According to the technology, the cadastral evaluation of real estate units (land plots with buildings located on them, isolated premises) differs from the cadastral valuation of land, so almost all steps in the pilot project had to be developed from scratch. This concerns the development of an evaluation methodology, software, collection of information, and others.

For example, while collecting input information about real estate objects for their evaluation, it turned out that no information resource contained it in a sufficient volume. Also, the databases are not automatically compared. To fill such information gaps, it is necessary to take additional steps - aerial photography, visual inspection, drawing the objects of evaluation, etc. Such work made it possible to increase the completeness of data about the properties from 55\% to $90 \%$ (Fig. 3) [4].

a)

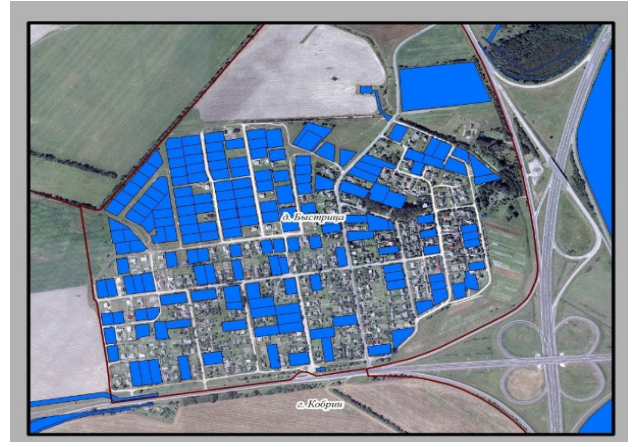

city border

registrated land plots b)

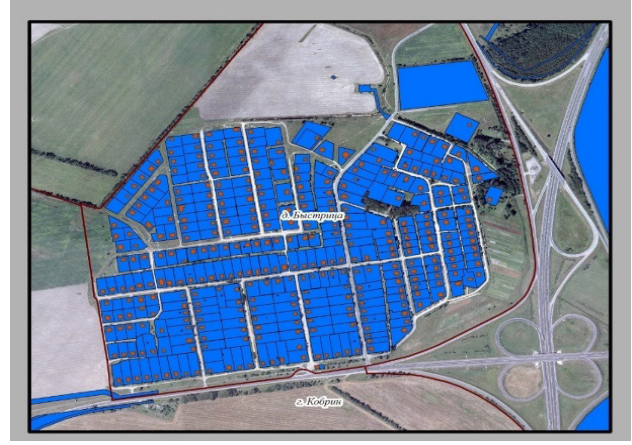

city border

buildings that were formed during the pilot project

land plots that were formed during the pilot project

Fig. 3. Completeness of spatial information: a) before pilot project; b) after pilot project 
According to the results of the pilot project, $80 \%$ of the real estate projects are residential. The number of unregistered objects across the country can be estimated to be about $20 \%$.

The results of the pilot project allowed the following:

- to take into account the individual characteristics of each property when performing a mass valuation;

- to determine the cadastral value of real estate with a minimum error of $5-15 \%$ as related to the market value, which corresponds to the best world practices as well as the requirements of the standards of the international association of tax valuations;

- to separate the value of the property into the value of its constituent parts (land, buildings). At the same time, the share of land plots in the value of a real estate unit was $30 \%$ on average (70\% for buildings).

Following the results of the pilot project, it can be confidently stated that the mass formation and evaluation of real estate can be successfully carried out. At the same time, the quality of the evaluation results corresponds to the quality of the world's best practices.

Besides all of the above ways of using the results of a centralized valuation of land, the mass valuation of real estate objects can be used in the following directions [4]:

- Lending. When preparing decisions on granting loans, the cadastral value of real estate may be used as a collateral value of the property to secure the loan. This will help reduce the time of the decision-making process on granting a loan, reduce the cost of the borrower to get a loan, and minimize the risks of banks associated with possible mistakes in determining the collateral value.

- Insurance. As a basis for determining the insurance value of a property, for purpose of insurance investment portfolio management as well.

- Accounting. The possibility of recording the cadastral value of real estate in a balance sheet as the least expensive way of determining the objective (real) value of objects. At the same time, individual valuation can be an alternative way to determine the cost.

- Real estate estimation. The cadastral value and the method of its determination will be a reference point in determining the market value in the process of individual assessment. The availability of information on the changes in the cadastral value of all real estate in the country will allow one to predict (simulate) possible changes in the future.

- Management decision. The use of the cadastral value of real estate objects when making a non-monetary contribution to the statutory fund of a legal entity as well as a benchmark for determining the market value for the purchase or sale of real estate objects (primarily in inactive real estate markets). 
So, all of the advantages point to the transition to a new taxation system instead of the existing two separate taxes.

Therefore, a draft law has been prepared in the Republic of Belarus that will allow us to scale the pilot project on the whole territory of the country. It has been approved by more than 30 departments and is now at the final stage of signing.

\section{Conclusion}

In conclusion, we would like to note that the system of mass valuation in the Republic of Belarus is a constantly developing organism. It has been designed thanks to the initiative of the State Committee on Property of the Republic of Belarus and their representative in the sphere - the National Cadastral Agency. The National Cadastral Agency tends:

- to use as much as possible the achievements in the sphere of information technologies,

- to automate the processes, especially the collecting, processing, and accumulation of information,

- to increase the accuracy of different types of information,

- to follow global trends in mass valuation.

The mass valuation of real estate units and changing the taxation system of real estate are the expected changes in the near future in the Republic of Belarus.

\section{References}

[1] Kodeks Respubliki Belarus' о zemle [Кодекс Республики Беларусь о земле], [on-line:] http://etalonline.by/?type=text\&regnum=Hk0800425\#load_text_none_1_[access: 05.06.2018].

[2] Postanovleniye Gosudarstvennogo Komiteta po Imushchestvu Respubliki Belarus' 29 iyunya 2015 g. № 27 Ob utverzhdenii Instruktsii o poryadke provedeniya kadastrovoy otsenki zemel', zemel'nykh uchastkov naselen punktov, sadovodcheskikh tovarishchestv i dachnykh kooperativov, zemel', zemel'nykh uchastkov, raspolozhennykh za predelami naselennykh punktov, sadovodcheskikh tovarishchestv i dachnykh kooperativov [Постановление Государственного Комитета по Имуществу Республики Беларусь 29 июня 2015 г. № 27 Об утверждении Инструкции о порядке проведения кадастровой оценки земель, земельных участков населенных пунктов, садоводческих товариществ и дачных кооперативов, земель, земельных участков, расположенных за пределами населенных пунктов, садоводческих товариществ и дачных кооперативов], [on-line:] http://pravo.by/document/?guid=12551\&p0=W21530130\&p1=1 [access: 02.06.2018]. 
[3] Obnovlen grafik provedeniya kadastrovoy otsenki [Обновлен график проведения кадастровой оценнки], [on-line:] http://nca.by/rus/news/ group_ m12=4 page_m12=1 news_m12=5645.txt [access: 08.06.2018].

[4] Bydłosz J.: Przyszłe obiekty katastru 3D w Polsce [Future Objects of 3D Cadastre in Poland]. Acta Scientiarum Polonorum Administratio Locorum, No. 16 (4), 2017, pp. 231-237.

[5] Work materials of National Cadastral Agency.

[6] Rącka I.: Jakość informacji na rynku nieruchomości w Polsce [The Quality of Information on the Real Estate Market in Poland]. Problemy Jakości, nr 4, 2017, pp. 19-25.

[7] Analiticheskiy obzor. Analiz rynka nedvizhimosti [Аналитический обзор. Анализ рынка недвижимости], [on-line:] http://www.nca.by/rus/analis/ analiz_rn_minsk [access: 04.06.2018].

[8] Gotovyye issledovaniya rynka nedvizhimosti [Готовые исследования рынка недвижимости], [on-line:] http://analytics.nca.by [access: 06.06.2018].

[9] Otsenka stoimosti ob"yektov grazhdanskikh prav: Poryadok kadastrovoy otsenki zemel', zemel'nykh uchastkov po vidam funktsional'nogo ispol'zovaniya zemel" "Zhilaya usadebnaya zona» (vklyuchaya sadovodcheskiye tovarishchestva $i$ dachnyye kooperativy) $i$ "Rekreatsionnaya zona» [Оиенка стоимости объектов гражданских прав: Порядок кадастровой оценки земель, земельных участков по видам функциинального использования земель "Жилая усадебная зона» (включая садоводческие товарищества и дачные кооперативы) и «Рекреациионная зона»], [on-line:] http://www.tnpa.by/\#!/ FileText/494276/366877 [access: 01.06.2018].

[10] The State Land value register, [on-line:] http://vl.nca.by [access: 07.06.2018].

[11] Pilot project "Mass formation and cadastral valuation of property covering the Soviet district of Minsk and Kobryn town and district in the Brest region", [on-line:] http://nca.by/image2/guidbook.pdf [access: 03.06.2018].

\section{Rozwój wyceny masowej w Republice Białorusi}

Streszczenie: Artykuł dotyczy obecnej i przyszłej sytuacji w systemie wyceny masowej w Republice Białorusi. Autorki koncentrują się na wykorzystaniu różnych typów informacji w procesie wyceny. W artykule omówiono masową wycenę gruntów w obszarach miejskich i wiejskich, także położonych poza siecią osadnicza, gruntów o charakterze ogrodniczym i letniskowym. Analizie nie poddano natomiast wyceny masowej gruntów rolniczych.

\section{Słowa}

kluczowe: wycena masowa, informacje rynkowe, projekt pilotażowy, Narodowa Agencja Katastru, procedury szacowania 